\title{
Displayable Identifier Indicator
}

National Cancer Institute

\section{Source}

National Cancer Institute. Displayable Identifier Indicator. NCI Thesaurus. Code C70973.

An indicator that can be set or unset in order to signal whether the identifier is intended for human display and data entry as opposed to pure machine interoperation. 